\title{
Description of breeding burrows of janitor fish (Pterygoplichthys spp.) in Agusan River, Butuan City, Philippines
}

\author{
Florence Jhun F. Almadin and Joycelyn C. Jumawan
}

\begin{abstract}
Pterygoplichthys spp., locally known as janitor fish, has been documented to have spread all over the freshwater habitat of the Philippines. It is now threatening the delicately balanced freshwater ecosystem of Agusan River, the third largest river in the Philippines. This species is believed to be exported as an aquarium pet and accidentally escaped from fish farms. This catfish is naturally distributed in South America and Africa and has adapted and reproduced very well in the Philippine condition. Pterygoplichthys spp. construct and maintain burrows in the banks of the rivers and lakes in which they live. It is speculated that the breeding burrow contributes to bank erosion and suspension of sediments in the water-column leading to alterations in the river ecosystem, hydrology, and river bank deformations. We conducted field survey in the riverbanks of five selected Barangays (Tagabaca, Buhangin, Mahay, Baan and Bading) in lower Agusan River, Butuan City, Philippines. A total of 116 burrows were measured and characterized in this study. The burrow depths ranged from 20.32 to $114 \mathrm{~cm}$ (average $=\mathbf{5 9 . 4 1}$ \pm 19.94); burrow entrance heights ranged from 5.08 to $25.68 \mathrm{~cm}$ (average $=12.18 \pm 4.07$ ); the burrow entrance widths ranged from 5.08 to $38.51 \mathrm{~cm}$ (average $=13.90 \pm 5.52)$. Burrow entrance width increases with an increase in burrow entrance height. Similarly, the burrow depth also increases with increasing burrow entrance height. Most burrows occur in groups and consisting of simple structures. A combination of submerged and exposed burrows was observed. The information gathered from this study may be helpful in explaining the habitat condition and the reproductive success on this invasive catfish in the Philippines.
\end{abstract}

Keywords - Agusan River, burrows, invasive species, janitor fish, Pterygoplichthys

\section{INTRODUCTION}

Introduced aquarium ornamental fishes have contributed to fish fauna diversity in the Philippines. In fact, most of the aquatic organisms with invasive reports are introduced alien species from the ornamental fish industry. Most of these introduced alien species coming from South America and Africa have adapted and reproduced very well in the Philippine

Manuscript received March 30, 2016.

F.J.F. Almadin is with the Biology Department of CARAGA State University, Ampayon, Butuan City, Philippines as a lecturer. He is also a MS Biology student at this institution.

J. C. Jumawan is an Associate Professor at CARAGA State University, Ampayon, Butuan City, Philippines. She finished PhD Biology at University of the Philippines, Diliman, Quezon City. condition [1][2]. In the Philippines, well-known cases of biological invasion are the freshwater fishes that have been introduced to freshwater habitats [3]. Pterygoplichthys disjunctivus and Pterygoplichthys pardalis locally known as janitor fish have been introduced to the Philippines either by accidental or intentional releases. There have been reports of Pterygoplichthys invasion in Agusan River, Davao del Norte and Agusan del Sur provinces [5]. Recently, one of these two invasive catfish, $P$. disjunctivus was reported from the Agusan Marsh [5].

Pterygoplichthys construct burrows in the banks of the rivers and lakes in which they live. This behavior lends much to explaining the reproductive capacity of the fish and its success as an invasive species in the Philippines. The burrows were used for reproduction but also allow survival during drought [6]. Their burrowing behavior in river banks may contribute to water turbidity and soil erosion [7][2]. It is speculated that the breeding burrow contributes to bank erosion and suspension of sediments in the water-column leading to alterations in the river environment and reduction of available potable water to human settlements in the area.

Freshwater biology in Agusan River has not yet been thoroughly explored by researchers, which leads to the apprehension that the presence of janitor fish may change the present aquatic faunal composition before this can be fully studied. There is need to for scientific research to provide a baseline information on hydrology, sediment dynamics, soil erosion and bank deformations, ecology as prerequisite to any interventions and development in the Agusan River and its tributaries [8][2]. Thus, this study aims to conduct field survey to establish information on burrow attributes of janitor fish in the Agusan River, Southern Philippines.

\section{MATERIALS AND METHODS}

\section{A. Description of the Study Area}

The Agusan River is the third largest river in the Philippines. The word "Agusan" comes from an "Agasan" which means "where water flows" and "where food was in abundance", but its pronunciation was corrupted by the Spanish conquistadores [9]. This river has a watershed of $11,932 \mathrm{sq} \mathrm{km}$ [10] which drains into a coastal plain. Its annual rainfall within the watershed ranges from 2000 to $4000 \mathrm{~mm}$. along the eastern 
half of the watershed, most rain come during the months of October to March. The water in the Agusan River and its other major tributaries (Simulao, Adgaon and Unayan Rivers), runs in a unidirectional flow [9]. At the middle of the river is where the Agusan Marsh situated. An extensive floodplain in Eastern Mindanao where rivers, creeks and tributaries mainly in the provinces of Agusan del Norte, Agusan del Sur and Compostela Valley converge and drain northward to the Agusan River and into Butuan Bay [8].

\section{B. Field Survey}

Field survey was carried out during late January (during 2015 El Niño season). The burrows survey was in the lower Agusan River, Butuan City with five sampling stations (Fig. 2): (Barangay Tagabaca, Barangay Buhangin, Barangay Mahay, Barangay Baan, and Barangay Bading). The shoreline was visually inspected, and the survey was done during good weather conditions and daylight hours. The visual hunt was focused along a single bank during passage upstream and on the opposite bank during the return journey downstream. The search for burrows consisted of traveling with small boat slowly within and about 5 to $10 \mathrm{~m}$ from the targeted shore. The geographic coordinates of burrow sites was determined using a GPS device.

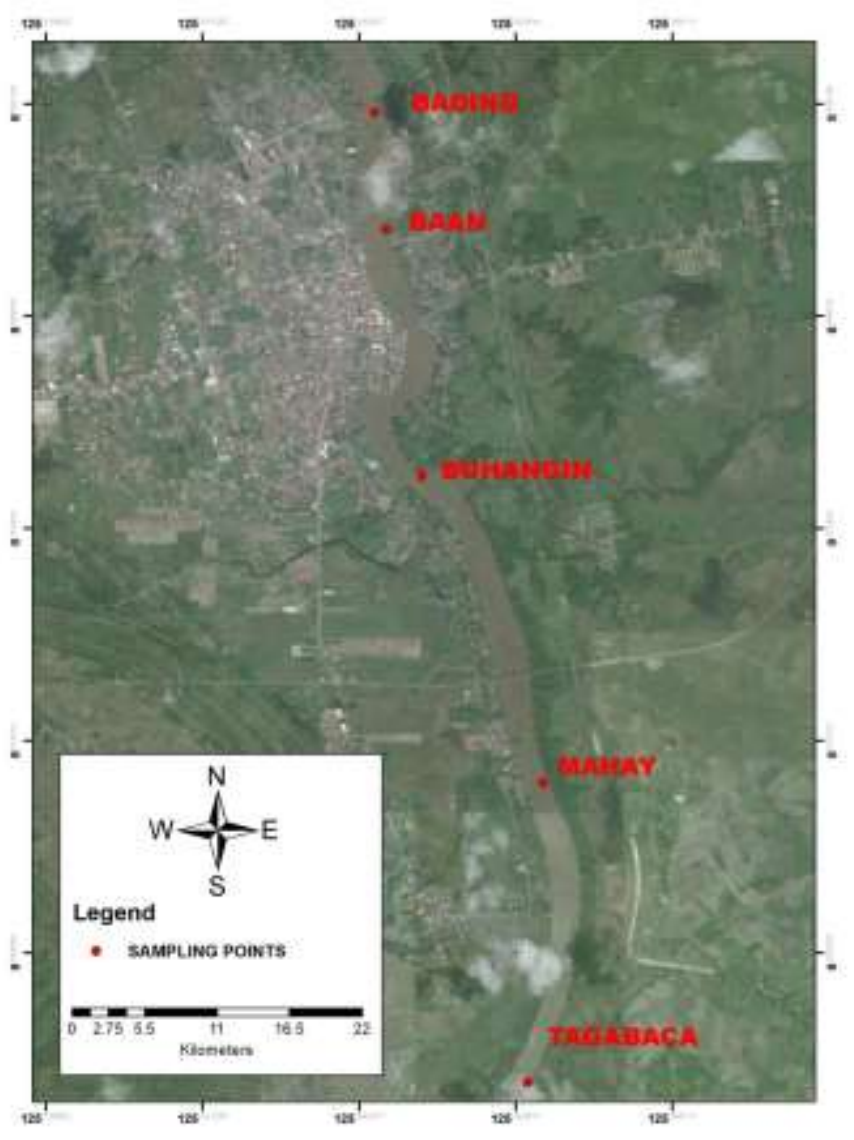

Fig. 1. Map of lower Agusan River showing the selected sites.

\section{Burrow measurement and assessment}

As suggested by Nico et al. [11] the probability of detecting burrows varied within and among sites due to local conditions (e.g., water levels, water clarity, type and extent of shoreline cover). A 20 meter transect line was established on the selected sampling site. Bank-holes that are degraded and are impossible to confirm whether the "burrow-like" structure was created by Pterygoplichthys, was noted and not included in subsequent burrow analyses [11]. Burrows and surrounding habitat was photographed with a digital camera. The following burrow attributes that was measured and characterized were: burrow length, maximum width of entrance, maximum height of entrance, tunnel shape, burrow condition, and occupancy of burrows (active or abandoned). Measurement and characterization of these burrows was based on the keys described by Nico et al. [11]. Measurement was employed by the following equipment and apparatus: meter sticks, tape measures, and adjustable T-squares.

\section{RESULTS AND DISCUSSION}

The field sampling was done early morning when the water level of the river is still low and was done first at the upstream of lower Agusan River, Butuan City in Barangay Tagabaca and Barangay Mahay. On the following day, field sampling continued in the midstream consist of two Barangays (Barangay Buhangin and Barangay Baan) and downstream which is Barangay Bading. Diverse burrows were observed in the sampling area which makes it difficult in identifying the janitor fish burrows but during close inspections and measurements of the burrows and with the description given by Nico et al. [11], verifying it to have been excavated by the janitor fish makes it possible. During the study period, a total of 212 suspected burrows were observed and counted but only 116 burrows were considered and documented which are believed to be excavated by the Pterygoplichthys. All burrows that were observed in the five Barangays were exposed due to low water level which is evident by the water line markings in the river banks, but during high tide all of these burrows are shroud by the water. It is also believed that more burrows are present but unable to be detected due to water turbidity and unpredicted slope of the river banks in the Agusan River, thus the possibility of observing and detecting janitor fish burrows below water level is impossible.

Burrows were observed in all the riverbanks of the five Barangays sampling sites. Distribution of the burrows in the five sampling sites are not uniform, it is scattered in different areas. Most burrows are clustered; some are in pair and individual. In Barangay Baan and Barangay Tagabaca, the burrows are mostly single burrows with combination of both exposed and partially submerged burrows. In Barangay Buhangin and Barangay Mahay, the burrows are individually scattered, some burrows are arranged differently, In Barangay Bading, the burrows are aligned and positioned up and down alternately (Fig. 2). 


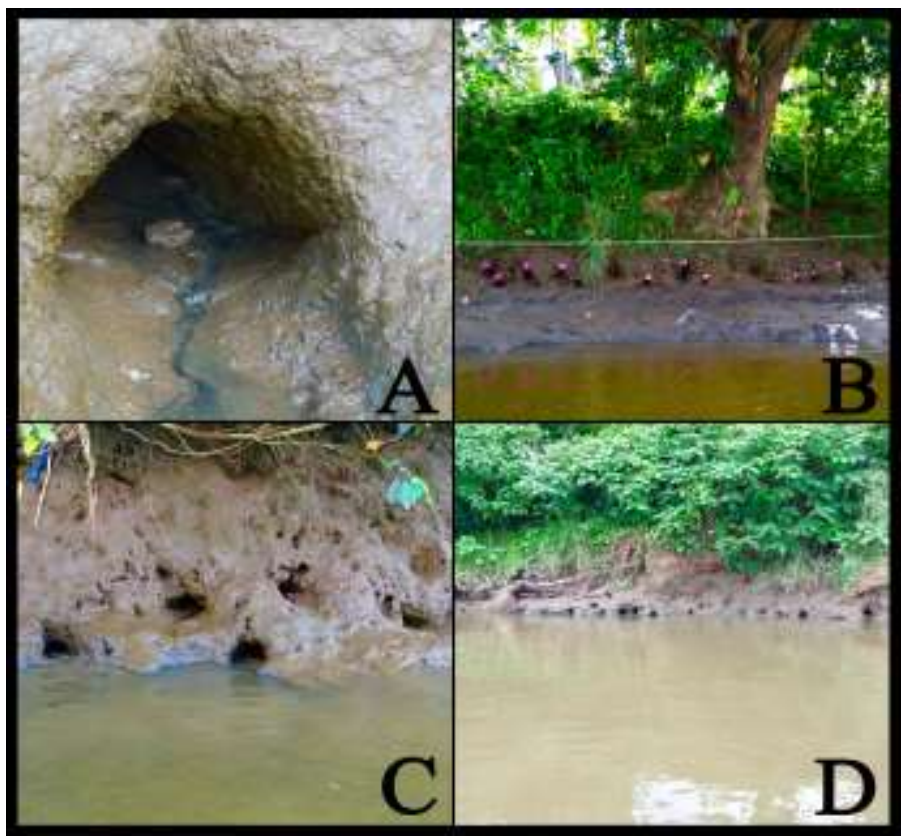

Fig. 2. Pterygoplichthys burrows found in Lower Agusan River. 2A. Typical of many burrow opening are triangular in shape. $2 \mathrm{~B}, \mathrm{C}$, and D. Exposed and stable burrows in selected Barangays in Lower Agusan River.

In general, the burrows excavated by Pterygoplichthys in the Lower Agusan River have the following dimensions presented in Table I. The burrow depths ranged from 20.32 to $114 \mathrm{~cm}$ (average $=59.41 \pm 19.94)$; burrow entrance heights ranged from 5.08 to $25.68 \mathrm{~cm}$ (average $=12.18 \pm 4.07$ ); the burrow entrance widths ranged from 5.08 to $38.51 \mathrm{~cm}$ (average $=13.90$ $\pm 4.52)$.

TABLE I: SUMMARY OF THE DIMENSIONS OF BREEDING BURROWS EXCAVATED BY PTERYGOPLICHTHYS SPP. ALONG THE LOWER AGUSAN RIVER, BUTUAN CITY $(\mathrm{N}=116)$.

\begin{tabular}{ccccc}
\hline \hline $\begin{array}{c}\text { Burrow } \\
\text { Dimensions }\end{array}$ & Minimum & Maximum & Average & $\begin{array}{c}\text { Standard } \\
\text { Deviation }\end{array}$ \\
\hline Depth $(\mathrm{cm})$ & 20.32 & 114.3 & 59.41 & 19.94 \\
$\begin{array}{c}\text { Entrance height } \\
(\mathrm{cm})\end{array}$ & 5.08 & 25.68 & 12.18 & 4.07 \\
$\begin{array}{c}\text { Entrance width } \\
(\mathrm{cm})\end{array}$ & 5.08 & 38.51 & 13.90 & 4.52 \\
\hline \hline
\end{tabular}

The burrow dimensions were positively correlated. For example, the burrow entrance width increases with an increase in burrow entrance height (Fig. 2A). Similarly, the burrow depth also increases with increasing burrow entrance height (Fig. 2B). Determining the relationship among burrow dimensions may help us predict the relative sizes of the burrows in the future. This may also give us information such as determining the relative body size of the Pterygoplichthys present in the Lower Agusan River and be able to explain their reproductive capacity and their population sizes as well.
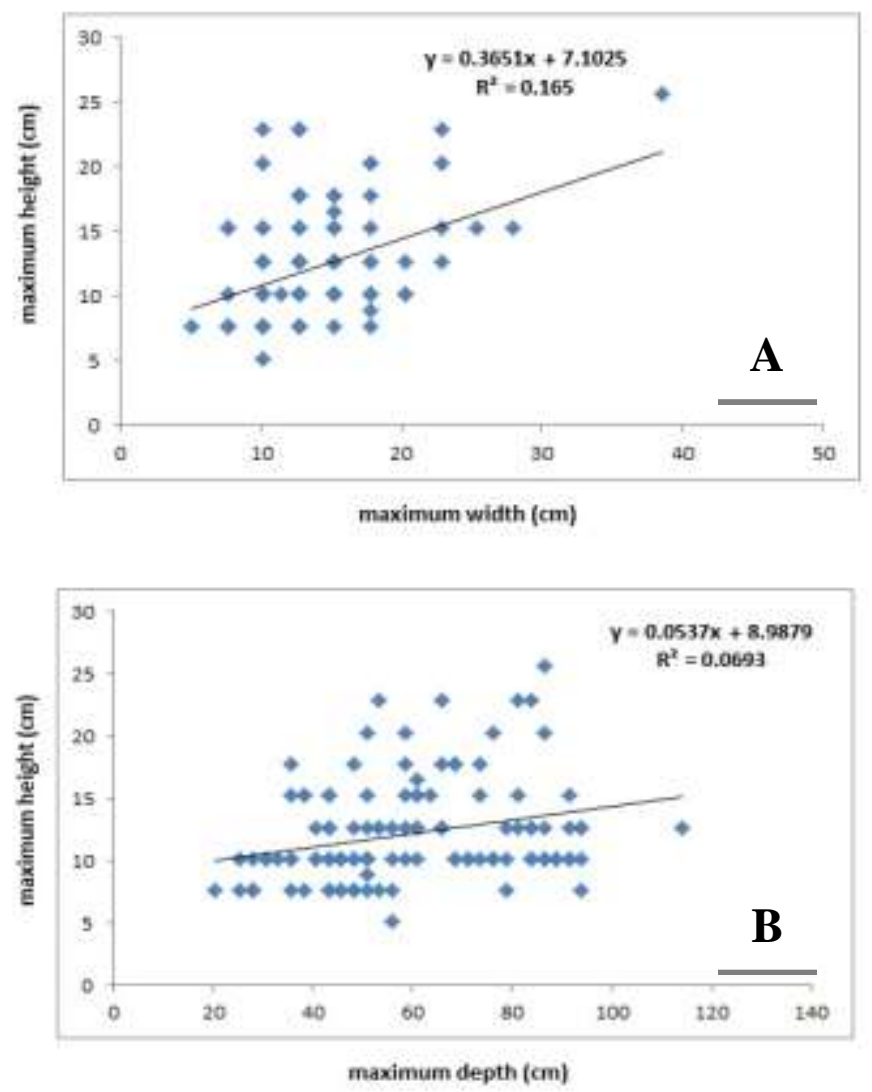

Fig. 3. Overall relationship between the dimenshions of the Pterygoplichthys burrows along the Lower Agusan River $(n=116)$. 3A.Relationship between burrow entrance height and width (adjusted $\left.\mathrm{R}^{2}=0.165, \mathrm{p}<0.05\right)$. 3B. Relationship between burrow entrance height and depth (adjusted $\mathrm{R}^{2}=0.0693, \mathrm{p}<0.05$ ).

Pterygoplichthys are said to excavate and maintain burrows for spawning and nesting habitat [11]. The burrows are reportedly excavated by adult males. Knowledge on burrow morphology and attributes is helpful to determine the behavioral mechanisms of the burrow occupants [13]. It is also use in classifying burrows species based on burrow morphology and architecture [14]. Also it is helpful in estimating the total number of population of the burrow occupants in certain area [15]. Nico et al. [11] mentioned that Pterygoplichthys generally excavate their burrows in shoreline habitats of rivers and canals already prone to erosion. They typically select relatively steep portions of banks with soils friable enough to dig into, yet stable enough to not collapse easily [11]. 


\section{CONCLUSION}

The detailed description of how Pterygoplichthys spp. excavate burrows has not yet been reported on literatures. However these burrows play an important role in their life cycle. Pterygoplichthys spp. excavate and maintain burrows in the river banks. Complete measurements were taken on 116 burrows observed. Results indicate that there was a positive correlation between burrow entrance height and width; and between burrow entrance height and depth. Thus, this study of burrow attributes of Pterygoplichthys spp. may enable us to explain; its ecological implications, its breeding behavior and its survival skills hence becoming as an invasive species, especially in Lower Agusan River.

\section{REFERENCES}

[1] Fishbase, 2006. http://www.fishbase.org

[2] The Journal of Environmental Science and Management (JESAM). 2007. Vol.10 No. 2 University of the Philippines Los Baños (UPLB).

[3] Hubilla, M., F. Kis, and J. Primavera. 2007. Janitor fish Pterygoplichthys disjunctivus in the Agusan Marsh: a threat to freshwater biodiversity. J. Environ. Sci. Mgt. 10(1): 10-23.

[4] Hubilla-Travis, M., Primavera, J., Babaran, P., Quinitio, G., Sanares, R., Flecker, A., 2010 (unpublished). Stable Isotope evidence of dietary and trophic overlap among native and exotic fish in a tropical floodplain ecosystem. Unsubmitted article for publication, Journal for biological Invasions.

[5] Hubilla, M. and F. Kis. 2006. Janitor Fish in the Agusan Marsh: a Threat to Freshwater Biodiversity. The Mouseion, Bi-annual newsletter of the UPV Museum of Natural Sciences v. 1, no. 4, p. 2-3.

[6] Hoover, J.J., Killgore, K.J., and Cofrancesco, A.F., 2004. Suckermouth Catfishes: Threats to Aquatic Ecosystems of the United States? ANSRP Bulletin 04(1): 1-9.

[7] Hubilla, M., Kis, F., and Primavera, J., 2010. Native and Exotic fish in the Agusan Marsh: a

[8] threat to freshwater biodiversity. Biological Invasion Journal. 10(1): 10-23.

[9] Primavera, J and Tumanda, M. 2007. The Agusan Marsh: A situationer with focus on scientific aspects. Proceeding of the 1 st scientific conference on the Agusan Marsh, 5-14pp.

[10] DENR-NIPA. Undated. Agusan Marsh Management Plan. Conservation of Priority Protected Areas Project, DENR-NIPA.

[11] CTI-Halcrow, 2006. Agusan River Basin Master Plan.

[12] Nico, L. G., H. L. Jelks, and T. Tuten. 2009. Non-Native suckermouth armored catfishes in Florida: Description of nest burrows and burrow colonies with assessment of shoreline conditions. ANSRP Bulletin, Vol-09-01. Vicksburg, MS: U.S. Army Engineer Research and Development Center.

[13] Clarke, K.R., and Warwick R. M., 2001. Change in Marine Communities: an approach to statistical analysis and interpretion, 2nd edition. Plymouth, United Kingdom: PRIMER-E.

[14] Herrel, A., Choi, H.F., Dumount, E., De Schepper, N., Vanhooydonck, B., Aerts, P., and Adriaens, D., 2011. Burrowing subsurface locomotion in anguiliforr fish: behavioral specializations and mechanical constraints. The journal of experimental biology, 214(Pt 8), 1379-85). http://dx.doi.org/10.1242/jeb.051185

[15] Nickell, L.A. and Atkinson, R.J. 1995. Functional morphology of burrows and trophic modes of three thalassinidean shrimp species, and a new approach to the classification of thalassinidean burrow morphology, 128, 181-197.

[16] Noro, C. K., and Buckup, L. 2010. The burrows of Parastacus defossus (Decapoda: Parastacidae), a fossorial freshwater crayfish from southern Brazil. Zoologia (Curitiba, Impresso), 27(3), 341-346. 